\title{
Literasi Internet Untuk Meminimalisir Dampak Konten Negatif Pada Ibu-Ibu PKK Desa Citeras
}

\author{
Helena Nurramdhani Irmanda*, Nurul Chamidah \\ Fakultas Ilmu Komputer \\ Universitas Pembangunan Nasional Veteran Jakarta \\ email: helenairmanda@upnvj.ac.id
}

\begin{abstract}
Internet rapid use in daily life has led to lifestyle changes. Internet is not only used by adults but also children. The Family Welfare Empowerment (PKK) action as the vanguard in the family has goals to create a family with noble character. It is important for PKK mothers to understand internet literacy in order to educate their children in healthy internet use so that the negative impact can be minimized. Based on the situation analysis, problems in Citeras village can be formulated, namely the need to increase the understanding of Citeras village PKK mothers regarding internet literacy. The solution to this problem is to conduct training activities on internet literacy and use of parental control applications. This activity aims to improve the competence of PKK mothers so that they can monitor their children in using the internet positively. This training has been carried out well. This is reinforced by the data from the internet usage survey, the high category $\mathrm{N}$-gain value of 96,15, and the results of the survey on the implementation of activities to the community which received a positive response from the participants.
\end{abstract}

Keywords: literacy, internet, application, parental control

\begin{abstract}
Abstrak
Pesatnya penggunaan internet dalam kehidupan sehari-hari membawa perubahan pola hidup. Internet tidak hanya digunakan oleh orang dewasa melainkan juga anak-anak. Gerakan Pemberdayaan Kesejahteraan keluarga (PKK) sebagai garda terdepan didalam keluarga mempunyai cita-cita untuk mewujudukan keluarga yang berakhlak mulia. Ibu-ibu PKK penting untuk memahami literasi internet guna mendidik anaknya dalam penggunaan internet sehat sehingga dampak negatifnya bisa diminimalisir. Berdasarkan analisis situasi, dapat dirumuskan permasalahan pada desa Citeras yaitu perlunya peningkatan pemahaman ibu-ibu PKK desa Citeras mengenai literasi internet. Solusi dari permasalahan ini yaitu melakukan kegiatan pelatihan mengenai literasi internet dan penggunaan aplikasi parental control. Kegiatan ini bertujuan meningkatkan kompetensi Ibu-ibu PKK sehingga dapat memantau anak-anaknya dalam menggunakan internet secara positif. Pelatihan ini telah dilaksanakan dengan baik. Hal ini perkuat dengan data hasil survey penggunaan internet, nilai $N$-gain berkategori tinggi sebesar 96,15, serta hasil survey pelaksanaan kegiatan kepada masyarakat yang mendapat respon positif dari peserta.
\end{abstract}

Kata Kunci : literasi, internet, aplikasi, parental control

\section{PENDAHULUAN}

Teknologi di Indonesia berkembang pesat seiring dengan perkembangan penggunaan internet baik deri segi pengguna maupun aktifitas berinternet. Peningkatan jumlah pengguna internet di Indonesia pada tahun 2009 sebanyak 30

doi: https://doi.org/10.37859/jpumri.v4i2.2115 juta orang dan pada tahun 2018 menjadi sebanyak 171 orang, telah mengubah pola hidup masyarakat dalam berbagai bidang kehidupan [1]. Perlu disadari bahwa penggunaan internet sebagai dua buah mata pisau. Selain manfaatnya yang banyak, jika digunakan secara sembarangan, internet akan memberi 
dampak negatif. Pengguna internet yang baik adalah pengguna yang memahami dan mampu menerapkan literasi internet. Literasi digital atau internet adalah kemampuan untuk dapat untuk menggunakan media internet untuk dapat membuat dan memanfaatkan informasi yang didapat secara bijak, cerdas, tepat, dan sesuai dengan aturan sehingga komunikasi dan interaksi dalam kehidupan sehari-hari terbina dengan baik [2].

Internet dewasa ini, bukan lagi hanya digunakan oleh orang-orang dewasa melainkan digunakan juga oleh anak-anak. Pada saat menggunakan internet, selain anak-anak mendapat pengetahuan, anakanak juga dimungkinkan dapat terpapar hal-hal negatif seperti konten kekerasan, pornografi, dan lain-lain yang dapat menyebabkan gangguan pada perkembangan otaknya. Bimbingan kepada masyarakat sangat diperlukan agar dapat menggunakan internet secara positif. Hal ini bukan hanya tugas pemerintah melainkan orang tua juga mempunya peran untuk mendampingi anak-anak dalam memanfaatkan internet. Berdasarkan penelitian yang dilakukan oleh $\mathrm{T}$ Anggraini, EN Maulidya menyimpulkan bahwa sudut pandang orang tua terhadap penggunaan internet dapat mempengaruhi cara tumbuh, belajar, dan berinteraksi [3].

Di sisi lain, seorang ibu merupakan sosok perempuan mempunyai andil yang sangat besar dalam dalam pembentukan sebuah keluarga yang bermartabat. Untuk dapat mewujudkan cita-cita tersebut dibentuklah Gerakan Pemberdayaan Kesejahteraan Keluarga (PKK) [4]. PKK merupakan gerakan nasional sebagai garda terdepan didalam keluarga. Hal ini sejalan dengan visi PKK itu sendiri yaitu "Terwujudnya keluarga yang beriman dan bertaqwa kepada Tuhan Yang Maha Esa, berakhlak mulia dan berbudi luhur, sehat sejahtera lahir dan batin." [5]. Demi mewujudukan keluarga yang berakhlak mulia, salah satunya ibu-ibu PKK penting untuk memahami literasi internet guna mendidik anaknya dalam penggunaan internet sehat sehingga dampak negatifnya bisa diminimalisir.

Citeras adalah sebuah desa di kecamatan Rangkasbitung kabupaten Lebak Banten. Di Desa Citeras, PKK di tingkat desa mempunyai pengurus dan anggota, yang diketuai oleh Ketua Tim Penggerak PKK dan pengurus serta anggota terdiri dari Ibu-ibu, istri Perangkat Desa, Ibu atau istri tokoh-tokoh masyarakat yang ada di wilayah Citeras. PKK di Desa Citeras cukup aktif dalam berbagai kegiatan khususnya programprogram yang mendukung pemberdayaan perempuan. Berdasarkan hasil survey dan penjajakan awal, terdapat permasalahan pada desa Citeras yaitu perlunya peningkatan pemahaman ibu-ibu PKK desa Citeras Lebak Banten mengenai literasi internet dan menggunakan internet secara aman, untuk meminimalisir dampak konten negatif sehingga dapat memantau anak-anaknya dalam menggunakan internet.

\section{METODE PENGABDIAN}

Pelaksanaan kegiatan ini dimulai dari kegiatan mengidentifikasi masalah dari mitra yaitu dengan melakukan wawancara kepada pihak mitra untuk melihat masalah prioritas dari mitra. Setelah diketahui permasalahan dan kebutuhan dari mitra maka tahap selanjutnya adalah melakukan analisis berupa pengumpulan data dan informasi terhadap kebutuhan dari pelatihan yang akan dilaksanakan dalam hal ini yaitu pelatihan mengenai Literasi Internet untuk meminimalisir dampak konten negatif pada Ibu-Ibu PKK. Kegiatan pengabdian kepada masyarakat ini dilakukan secara daring melalui grup whatsapp, sehingga dibutuhkan media penyampaian materi yang dapat dengan mudah dipahami oleh peserta pelatihan. Media yang dibuat yaitu berupa video animasi. Tahapan pelaksanaan kegiatan pelatihan Literasi Internet untuk meminimalisir dampak konten negatif 
pada Ibu-Ibu PKK desa Citeras adalah sebagai berikut :

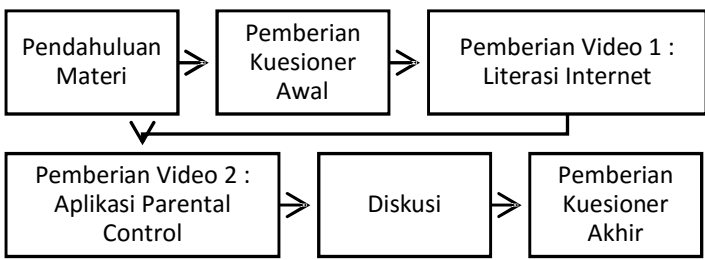

Gambar 1 Tahapan Pelatihan Literasi Internet

Berdasarkan Gambar 1. pelaksanaan pelatihan literasi internet terdiri dari 6 tahapan pertama yaitu pendahuluan materi. Pada tahapan ini merupakan perkenalan awal kepada Ibu-ibu PKK Citeras. Tim pelaksana memperkenalkan diri dan menjelaskan bahwa akan melakukan pelatihan mengenai literasi internet. Literasi internet artinya kemampuan yang dimiliki oleh seseorang untuk dapat mencari dan memanfaatkan informasi yang dibutuhkan dengan pemanfaatan internet secara sehat dan bertanggung jawab. Kemudian diberitahukan bahwa kegiatan pelatihan ini akan dibagi menjadi 4 sesi yaitu: Sesi kuesioner awal, sesi menonton video, sesi diskusi, dan sesi kuesioner akhir.

Tahapan kedua yaitu pemberian kuesioner awal / pretes untuk melihat pengetahuan awal dari peserta.. Peserta diminta untuk mengisi kuesioner awal. Peserta dapat mengakses kuesioner awal di link google form yang dibagikan. Adapun kuesioner awal ini terdiri atas 2 bagian yaitu survey penggunaan internet dan pretes.

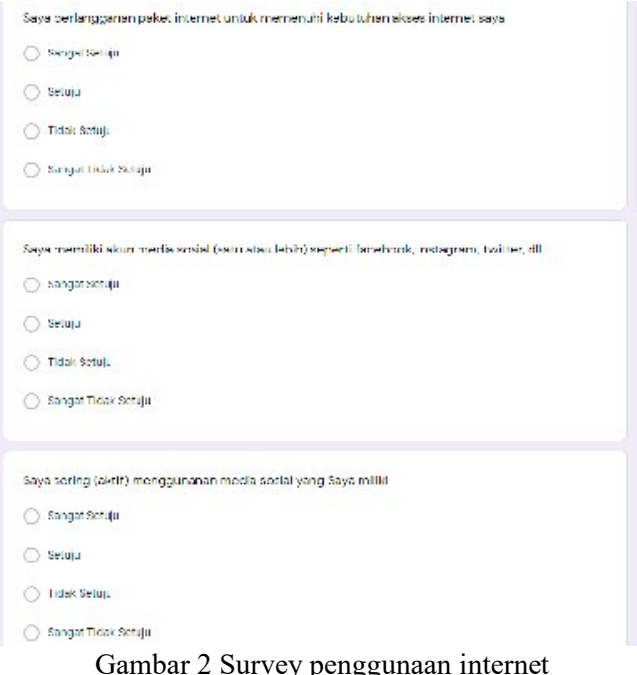

Gambar 2 Survey penggunaan internet

Survey penggunaan internet berisi pertanyaan-pernyataan tentang aktivitas peserta pelatihan sebagai pengguna intenet. Survey ini bertujuan untuk mengetahui pola penggunaan internet pada masyarat terutama di Indonesia.

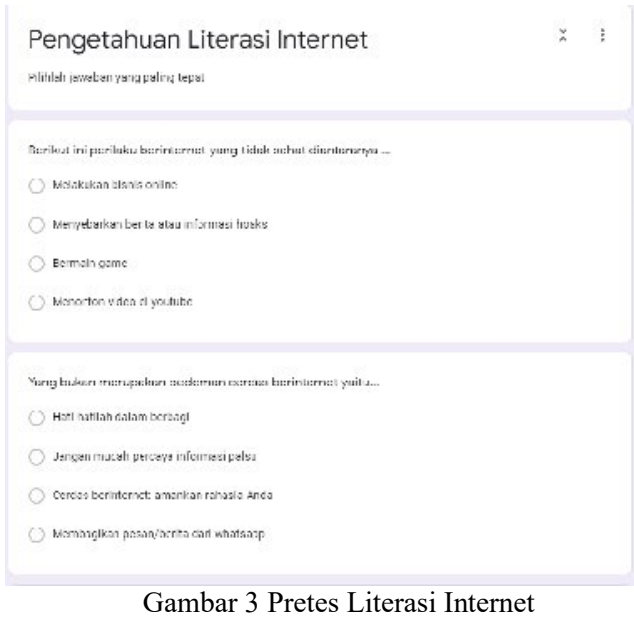

Pretes literasi internet berisi tentang pertanyaan yang menggali pemahaman peserta terkait materi literasi internet.

Tahapan ketiga yaitu pemberian video 1 mengenai literasi internet. Pada tahapan menonton video, peserta diberikan link youtube berisi video animasi mengenai literasi internet dan penggunaan aplikasi parental control menggunakan google Family Link. 

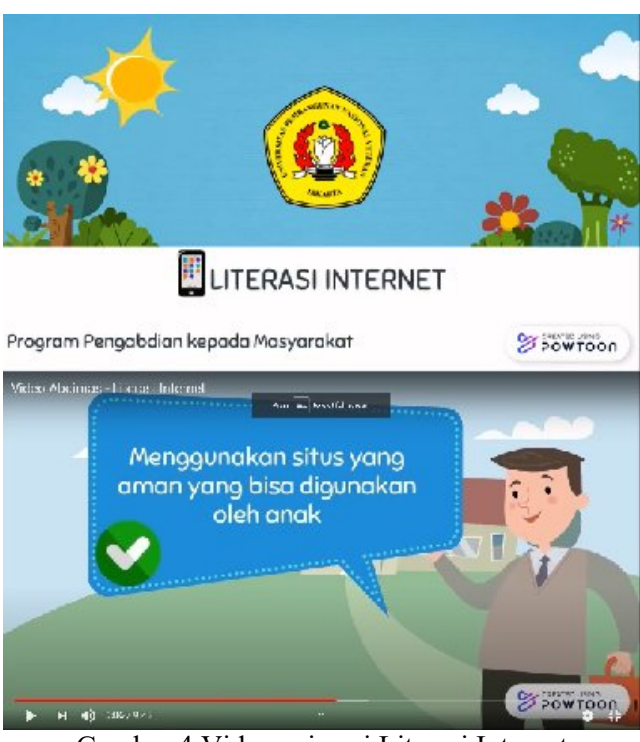

Gambar 4 Video animasi Literasi Internet

Pada video animasi literasi internet dijelaskan mengenai tantangan dan peluang perkembangan internet, pentingnya literasi internet, dan Gerakan literasi internet di keluarga.

Setelah menonton video 1, para peserta dipersilakan untuk menonton video 2 mengenai aplikasi parental control yang juga dibuat oleh tim pelaksana dan diunggah ke youtube.

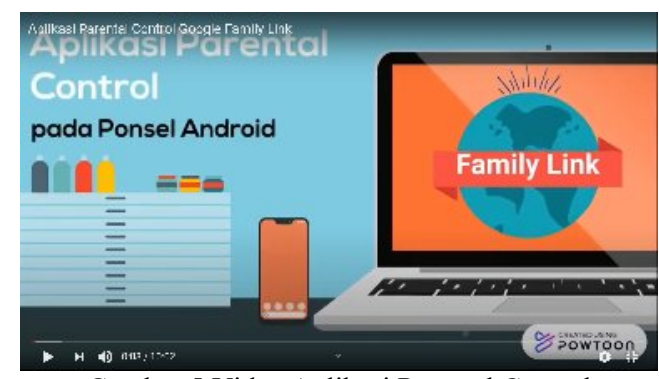

Gambar 5 Video Aplikasi Parental Control

Pada video animasi aplikasi parental control dijelaskan mengenai cara-cara penggunaan aplikasi android family link dari google untuk memantau dan mengatur aktivitas anak dalam berinternet.

Tahapan selanjutnya yaitu diskusi. Para peserta diperkenankan untuk bertanya jika ada hal dalam video yang masih belum dipahami. Peserta juga diperbolehkan untuk berbagi pengalaman menggunakan dan mengawasi anak dalam berinternet. diskusi dilakukan melalui chat di whatsapp grup.

Tahap terakhir yaitu pemberian kuesioner akhir / postes. Para peserta Peserta dapat mengakses kuesioner akhir di link google form yang dibagikan. Adapun kuesioner awal ini terdiri atas 2 bagian yaitu survey pelaksanaan pelatihan dan postes.

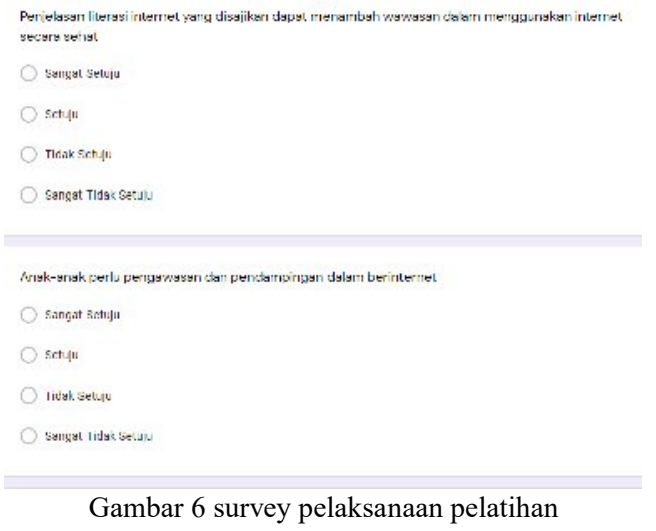

Survey pelaksanaan pelatihan ini berisi pertanyaan-pernyataan manfaat yang dirasakan oleh peserta mengikuti pelatihan ini. Sedangkan untuk postes. Soal-soal ini yang diujikan sama seperti pretes yang bertujuan untuk melihat ada tidaknya peningkatan pemahaman peserta pelatihan. Jawaban pretes dan postes diolah sehingga menghasilkan nilai yang dihitung dari jawaban benar dengan ketentuan sebagai berikut:

Nilai $=-\times 100$

Dari rumus 1 nilai dapat diketahui dari jumlah jawaban yang benar dibagi dengan jumlah jawaban benar maksimum yang bisa didapatkan dan dikali dengan $100 \%$. Untuk menghitung peningkatan literasi internet akan dihitung selisi antara nilai postes dan pretes.

$\mathrm{N}-$ gain $=\longrightarrow \quad 100$

Hasil skor N-gain dikategorikan ke dalam beberapa katergori antara lain : 
Tabel 1 Kategori N-gain [6]

\begin{tabular}{|l|l|}
\hline Presentase N-gain & Klasifikasi \\
\hline$>70$ & Tinggi \\
\hline $30<=$ N-gain $<=70$ & Sedang \\
\hline$<30$ & Rendah \\
\hline
\end{tabular}

\section{HASIL DAN PEMBAHASAN}

Kegiatan pengabdian kepada masyarakat dilaksanakan pada 9 Juli 2020 hingga 10 Juli 2020, dengan peserta IbuIbu PKK Desa Citeras sebanyak 13 orang. Pelaksanaan pelatihan literasi internet diselenggarakan menggunakan whatsapp grup. Hasil dari kuesioner awal yaitu survey penggunaan internet ditujukan pada Gambar 7.

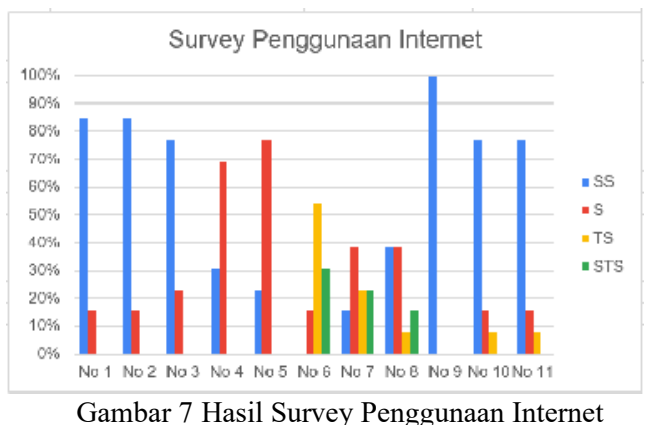

Berdasarkan Gambar 7 hasil survey penggunaan internet antara lain:

1. $85 \%$ peserta sangat setuju sering menggunakan internet dalam kegiatan sehari-hari, dan $15 \%$ peserta setuju.

2. $85 \%$ peserta sangat setuju berlangganan paket internet untuk memenuhi kebutuhan akses internet dan $15 \%$ peserta setuju.

3. $77 \%$ peserta sangat setuju memiliki akun media sosial (satu atau lebih) seperti facebook, instagram, twitter, dll, 23\% peserta setuju.

4. $31 \%$ peserta sangat setuju aktif menggunanan media sosial yang dimiliki, $69 \%$ peserta setuju.
5. $23 \%$ peserta sangat setuju Internet aman untuk transaksi jual beli, $77 \%$ setuju.

6. $15 \%$ peserta setuju sering mendapat kiriman yang tidak pantas (seperti pornografi, kekerasan, rasisme, dll) saat mengakses internet, $54 \%$ tidak setuju, dan 31\% sangat tidak setuju

7. $15 \%$ peserta sangat setuju terdapat konten yang berbahaya di internet seperti ajakan kegiatan asusila, terorisme, perdagangan narkoba, dll. yang berbahaya bagi masyarakat dan bangsa, 38\% setuju, 23\% tidak setuju, dan 23\% sangat tidak setuju.

8. $38 \%$ peserta sangat setuju internet dapat dijadikan sebagai alat atau sarana penipuan atau pencurian, $38 \%$ setuju, $8 \%$ tidak setuju, dan $15 \%$ sangat tidak setuju.

9. $100 \%$ peserta sangat setuju anak di bawah umur, harus dibatasi dalam menggunakan internet

10. $77 \%$ peserta sangat setuju perlu suatu aplikasi khusus yang mencegah keluarga untuk mengakses situs-situs berbahaya (yang berisi pornografi, kekerasan, kebencian, dll), $15 \%$ setuju, dan $8 \%$ tidak setuju.

11. $77 \%$ peserta sangat setuju internet sehat perlu dilaksanakan untuk membatasi konten yang berbahaya, $15 \%$ peserta setuju, dan $8 \%$ peserta tidak setuju.

Hasil analisis pretes, postes, dan gain ditunjukan pada Gambar 8. 


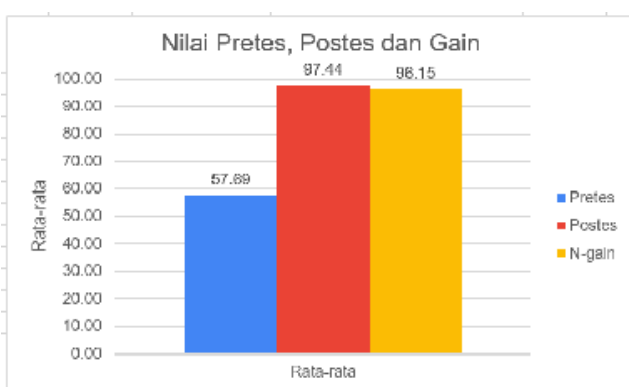

Gambar 8 Nilai pretes, postes, dan gain

Berdasarkan Gambar 8, dapat diketahui bahwa rata-rata nilai pretes adalah 57,69, rata-rata nilai postes adalah 97,44 , dan N-gain atau peningkatan nilai pretes dan postes yaitu 96,15 . Nilai N-gain yang diperoleh diklasifikasikan ke dalam kategori tinggi yang artinya dari pelatihan yang sudah dilaksanakan, terdapat peningkatan literasi internet untuk meminimalisir dampak konten negatif pada ibu-ibu PKK di desa citeras.

Selain itu, hasil survey pelaksanaan kegiatan pengabdian kepada masyarakat dideskripsikan pada Gambar 9.

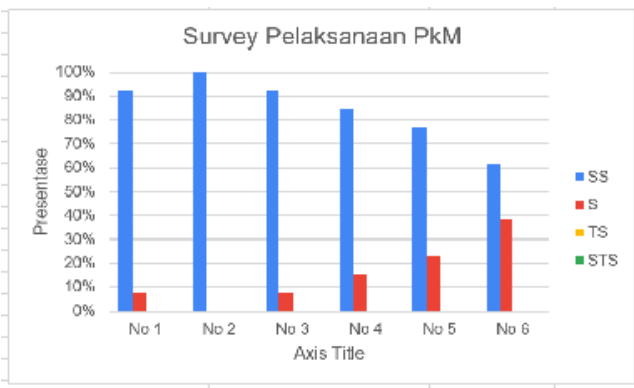

Gambar 9 Survey Pelaksanaan PkM

Berdasarkan Gambar 9 hasil survey pelaksanaan kegiatan pengabdian kepada masyarakat antara lain:

1. $92 \%$ peserta sangat setuju penjelasan literasi internet yang disajikan dapat menambah wawasan dalam menggunakan internet secara sehat, dan $8 \%$ setuju.

2. $100 \%$ peserta sangat setuju anakanak perlu pengawasan dan pendampingan dalam berinternet.
3. $92 \%$ peserta sangat setuju penggunaan aplikasi khusus (parental control) dapat mengurangi dampak negatif internet, dan $8 \%$ peserta setuju.

4. $85 \%$ peserta sangat setuju aplikasi pengawasan orang tua family link mudah digunakan dan $15 \%$ peserta setuju.

5. $77 \%$ peserta sangat setuju materi yang disajikan dalam video mudah dimengerti, dan $23 \%$ peserta setuju.

6. $62 \%$ peserta sangat setuju berminat mengukuti pelatihan-pelatihan berikutnya untuk menambah wawasan, dan $38 \%$ setuju.

Kegiatan pengabdian kepada masyarakat literasi internet untuk meminimalisir dampak konten negatif pada ibu-ibu PKK di desa citeras dinilai positif oleh peserta.

\section{SIMPULAN}

Berdasarkan Kegiatan pengabdian kepada masyarakat yang telah dilakukan dapat diambil kesimpulan bahwa pelatihan literasi internet untuk meminimalisir dampak konten negatif pada ibu-ibu PKK di desa Citeras telah dilaksanakan dengan baik. Hal ini perkuat dengan data hasil survey penggunaan internet, nilai $\mathrm{N}$-gain berkategori tinggi sebesar 96,15, serta hasil survey pelaksanaan kegiatan kepada masyarakat yang mendapat respon positif dari peserta. Kegiatan ini memiliki target jangka panjang yaitu menjadikan Ibu-Ibu PKK yang menggunakan internet secara positif dan dapat memanfaatkan internet untuk proses pembelajaran kepada anakanaknya.

\section{UCAPAN TERIMAKASIH}

Terima kasih kepada Lembaga Penelitian dan Pengabdian Masyarakat (LPPM) Universitas Pembangunan Nasional Veteran Jakarta yang telah memberikan dukungan dan mendanai 
program pengabdian kepada masyarakat ini. Tim pelaksana mengucapkan terima kasih juga kepada PKK Desa Citeras, Kecamatan Rangkasbitung, Kabupaten Lebak Banten yang telah mendukung dan mengapresiasi kegiatan ini.

\section{DAFTAR PUSTAKA}

[1] R. Santoso, H. A. Munawi, and D. Sukmawati, "PErkembangan Teknologi Informasi Dan Telekomunikasi Terhadap Perubahan Perilaku Masyarakat," in Prosiding Conference on Research and Community Services, 2019, vol. 1, no. 1, pp. 586-592.

[2] Kemendikbud, Materi Pendukung Literasi Digital. Jakarta: Kementerian Pendidikan dan Kebudayaan, 2017.

[3] T. Anggraini and E. N. Maulidya, "Dampak Paparan Pornografi Pada Anak Usia Dini," Al-Athfaal J. Ilm. Pendidik. Anak Usia Dini, vol. 3, no. 1, pp. 45-55, 2020.

[4] N. R. Riana, "Pelaksanaan Peran Tim Penggerak Pemberdayaan dan Kesejahteraan Keluarga (PKK) dalam Memberdayakan Perempuan (Studi tentang Program Pendidikan dan Keterampilan di Kecamatan Kaliori Kabupaten Rembang)," $J$. Adm. Publik, vol. 2, no. 5, pp. 851856, 2014.

[5] TPPKK, Pemberdayaan dan Kesejahteraan Keluarga. Jakarta: Tim Penggerak PKK Pusat, 2015.

[6] Z. Zuraida and others, "Penerapan Model Pembelajaran Problem Based Learning Dalam Meningkatkan Hasil Belajar Siswa Pada Konsep Sistem Ekskresi Manusia Di Kelas Xi Sma Negeri 1 Jangka Buya," J. Sos. Hum. Sigli, vol. 3, no. 1, pp. 171-180, 2020. 